\title{
Study of Phenolic Composition and Biological Activities Assessment of Olive Leaves from different Varieties Grown in Tunisia
}

\author{
Myriam Ben Salah ${ }^{1,2}$, Hafedh Abdelmelek ${ }^{1}$ and Manef Abderraba ${ }^{2}$ \\ ${ }^{1}$ Faculté des Sciences de Bizerte, Laboratoire de Physiologie Intégrée, 7021Jarzouna, Tunisia \\ ${ }^{2}$ Institut Préparatoire aux Etudes Scientifiques et Techniques, Unité de Recherche Physico-Chimie-Moléculaire, La Marsa
}

\begin{abstract}
In the present study, olive leaves of eight varieties were investigated for the total phenol and flavonoid content, for the major compound and for the in vitro antioxidant properties. The different varieties showed a high content of polyphenol and flavonoid. Oleuropein was the major compound of the leaf extract for all varieties. Also, olive leaves extract exhibited a good antioxidant activity and a reduced power, each variety showed its own feature. A significant negative correlation between anti-radical activities and oleuropein content was observed only for four varieties $(r$ $=-0.94$ ). The high oleuropein content and the important antioxidant activities of olive leaves extract could be useful sources for industrial extraction and pharmacological application in the promotion of health and prevention of damages caused by radicals.
\end{abstract}

Keywords: Olive leaves; Polyphenol; Flavonoid; Oleuropein; Antiradical activity; Reduced power; Antioxidant activity

\section{Introduction}

The high levels of free radicals in living systems can oxidize biomolecules, leading to tissue damage, cell death, or various diseases such as skin irritations, degenerative processes associated with ageing, cardiovascular diseases, arteriosclerosis, diabetes, neural disorders, and cancer [1-3]. Antioxidant compound can deactivate and scavenge free radical by donating hydrogen atom or chelating metals. Therefore, commercial antioxidants are in high demand, and most of them are synthesized, including butylated hydroxyanisole (BHA), butylated hydroxytoluene (BHT) and propyl gallate (PG). However, these synthetic antioxidants are reported to be toxic and carcinogenic in animal models $[4,5]$. Thus, there is a growing request and interest on natural and safer antioxidants found in various kinds of land plants, such as cereals, vegetables, fruits and herbs; in which tocopherol, vitamin C, carotenoid and polyphénols are good sources of antioxidant [6].

In the Mediterranean area, olive leaves are one of the by-products of farming of the olive grove; they can be found in high amounts in the olive oil industries (10\% of the total weight of the olives) and they accumulate during the pruning of the olive trees [7]. Olive leaves are considered as a cheap raw material which can be used as a useful source of high-added value products (phenolic compounds) [8]. Interestingly, the interest in the olive leaf and its chemical composition has recently been increasing. In fact, the olive leaves extract have been found to have anti-oxidative, anti-inflammatory and antimicrobial activities against bacteria and fungi [9-11]. Moreover, the olive leave extract exhibits anti-viral activities against several virus like haemorragic septicaemia rhabdovirus [12]. The main phenolic compound in olive leaves are oleuropein, verbascoside, ligstroside, tyrosol and hydroxytyrosol [13]. Somova et al. reported that oleuropein and its derivatives had various biochemical roles including hypotensive, coronary dilating antiarrhythmic action [14]. Furthermore, it was reported that these polyphenols could prevent low-density lipoprotein oxidation and platelet aggregation $[15,16]$.

The objective of the present study is to assess the amount of total phenolic and flavonoid content of ethanol extracts of olive leaves and then to evaluate their antioxidant properties.

\section{Material and Methods}

\section{Chemicals}

Ethanol (HPLC grade) and acetonitril (HPLC grade) was purchased from Alpha chimie, sodium carbonate was obtained from Prolabo. Sodium nitrite, sodium hydroxide, peroxdisulphate and Folin-Ciocalteu were purchased from Fluka (Buchs, Switzerland). 2,2diphenyl-1-picrylhydrazyl (DPPH) was from Sigma Co. (St. Louis, MO, USA). Oleuropein, Gallic acid, (+)-catechin, and aluminium chloride were obtained from Sigma-Aldrich (Steinheim, Germany). Butylated hydroxytoluene (BHT) was purchased from Sigma.

\section{Plant Material}

Experiments were carried out on olive leaves of 8 varieties from different origin; Sevillane (Spain), Rosicola and Meski (Italia), Lucques (France), Gerboua, Chetoui, Limouni and Chemlali (Tunisia). Leaves were collected on october 2010 (maturation period) in the National Agronomic Institute (Tunisia). The different cultivars from different origins were submitted to the same cultural conditions and the same geographical, geological, and climatic conditions. Leaves were dried on site in a microwave oven $(2500 \mathrm{MHz})$, three times for $2 \mathrm{~min}$ at maximum power. Dried leaves were powdered and stored in a dry place in the dark.

\section{Preparation of olive leaves extract.}

A mixture of ethanol and water $(20 \mathrm{ml}, 70: 30(\mathrm{v} / \mathrm{v}))$ was added to the olive leaves powdered $(1 \mathrm{~g})$. The mixture was left to stand for at least one week at room temperature in the dark. Subsequently, the solution was filtered using a $0.45 \mu \mathrm{m}$ filter paper. Each extract was stored at $+4^{\circ} \mathrm{C}$ until analysis [17].

\section{Determination of total polyphenol content.}

Total phenolics of olive leaves were determined using the FolinCiocalteu (F-C) reagent, according to the method described by Singelton et al. [18]. Folin-ciocalteu reagent contains metals like

*Corresponding author: Myriam Ben Salah, Faculté des Sciences de Bizerte, Laboratoire de Physiologie Intégrée, 7021 Jarzouna, Tunisia, Fax: +216 72590566 E-mail: ben_salah_myriam@yahoo.fr

Received May 25, 2012; Accepted August 13, 2012; Published August 15, 2012

Citation: Salah MB, Abdelmelek H, Abderraba M (2012) Study of Phenolic Composition and Biological Activities Assessment of Olive Leaves from different Varieties Grown in Tunisia. Med chem 2: 107-111. doi:10.4172/2161-0444.1000124

Copyright: $\odot 2012$ Salah MB, et al. This is an open-access article distributed under the terms of the Creative Commons Attribution License, which permits unrestricted use, distribution, and reproduction in any medium, provided the original author and source are credited. 
polytungston. Phenolic content from the sample reduces the metal and changes the colour from yellow to Prussian blue. The intensity of the colour is directly proportional to the phenolic content. In the experiment, each extract was diluted with the same solvent used for extraction to an appropriate concentration for analysis. An aliquot of $1 \mathrm{ml}$ of diluted extract was added to $5 \mathrm{ml}$ of deionized water and $1 \mathrm{ml}$ of $20 \% \mathrm{Na}_{2} \mathrm{CO}_{3}$. After shaking, the mixture was incubated for $3 \mathrm{~min}$ at room temperature. Then, $1 \mathrm{ml}$ of the diluted (F-C) reagent solution was added, and held for $30 \mathrm{~min}$ at $40^{\circ} \mathrm{C}$. The absorbance of the solution was then measured at $760 \mathrm{~nm}$ against a blank. The total phenolic content was expressed as mg of gallic acid equivalents (GAE) per gram of dry weight (mg GAE/g) through the calibration curve of gallic acid $\left(\mathrm{R}^{2}=\right.$ 0.99). The sample was analyzed in three replications [18].

\section{Total flavonoid}

Flavonoids are the most common group of polyphenolic compounds in the human diet and are found ubiquitously in plants. Also, they are commonly known for their antioxidant activities [19]. In our study, total flavonoid content was measured according to Dewanto et al. [20]. $250 \mu \mathrm{l}$ ethalonic leaves extracts appropriately diluted was mixed with $75 \mu \mathrm{NaNO}_{2}(5 \%)$. After $6 \mathrm{~min}, 150 \mu \mathrm{l}$ of $10 \% \mathrm{AlCl}_{3}$ and $500 \mu$ of $\mathrm{NaOH}(1 \mathrm{M})$ were added to the mixture. Finally, the mixture was adjusted to $2.50 \mathrm{ml}$ with distilled water. The absorbance versus prepared blank was read at $510 \mathrm{~nm}$. Total flavonoid contents of leaves (three replicates per treatment) were expressed as mg catechin equivalents per gram of dry weight ( $\mathrm{mg} \mathrm{CE} / \mathrm{g}$ ) through the calibration curve with catechin. The calibration curve range was $25-500 \mu \mathrm{g} / \mathrm{ml}\left(\mathrm{R}^{2}\right.$ $=0.99)$ [20].

\section{HPLC analysis of the olive leaves extracts}

The HPLC analysis given in the literature was used for identification and quantification of polyphenol compound [21]. HPLC analysis was performed on a KNAUER apparatus, manual injection valve, UV detector model 2500 using a column $250 \times 4.60 \mathrm{~mm}$ with percolumn, packing: Eurospher 100-5 C18. Data acquisition and quantitation were performed with Eurochrom software (KNAUER). The mobile phase was $79 \%$ distilled water acidified $(\mathrm{pH}=3)$ with $0.10 \mathrm{M}$ orthophosphoric acid (v/v, $1000: 2.30)$ and $21 \%$ acetonitrile (Carlo Erba, HPLC grade) acidified with $0.10 \mathrm{M}$ orthophosphoric acid (v/v, $1000: 2.30)$. The flow rate was $1 \mathrm{ml} / \mathrm{min}$, and the injection volume was $20 \mu$ l. Routine quantitation of oleuropein was assessed at $280 \mathrm{~nm}$. Run time was 37 min.

To calculate the oleuropein amount in the olive leaf extracts, a five-point calibration curve $\left(\mathrm{R}^{2}=0.99\right)$ prepared using the standard solutions (Tyrosol) with increasing concentrations.

\section{DPPH assay}

The electron donation ability of the obtained ethanol extracts was measured by bleaching of the purple-coloured solution of 1,1-diphenyl2-picrylhydrazyl radical (DPPH) according to the method of Hanato et al. [22]. Extracts $\left(1 \mathrm{ml}, 5-200 \mu \mathrm{g} \cdot \mathrm{ml}^{-1}\right)$ were added to $0.25 \mathrm{ml}$ of 0.20 $\mathrm{mM}$ DPPH methanolic solution. After an incubation period of $30 \mathrm{~min}$ at room temperature, the absorbance was determined against a blank at $517 \mathrm{~nm} \mathrm{[22].}$

Percentage inhibition of free radical DPPH (PI\%) was calculated as follow:

\section{$\mathrm{PI} \%=[($ Ablank - Asample $) / A$ blank $] \times 100$}

Where Ablank was the absorbance of the control reaction and $A$ sample was he absorbance in the presence of plant extract. Extract concentration providing $50 \%$ inhibition $\left(\mathrm{IC}_{50} \mu \mathrm{g} / \mathrm{ml}\right)$ was calculated from the log-dose inhibition curve regression equation prepared from the concentration of the extracts and the inhibition percentage. BHT was used as a positive control. Samples were analyzed in triplicate.

\section{$\beta$-carotene bleaching test}

The antioxidant activity of olive leaves extracts was evaluated according to a slightly modified version of the $\beta$-carotene bleaching method of Pratt [23]. $\beta$-Carotene ( $5 \mathrm{mg}$ ), $25 \mu \mathrm{l}$ of linoleic acid and 200 mg of Tween 40 (polyoxyethylene sorbitan monopalmitate) were mixed with $10 \mathrm{ml}$ of chloroform. Chloroform was removed at $50^{\circ} \mathrm{C}$, under vaccum, using a rotary evaporator (Heidolph, Germany). The resulting mixture was immediately added to $100 \mathrm{ml}$ oxygenated distilled water and was mixed well for $1-2 \mathrm{~min}$. Aliquots $(2.50 \mathrm{ml})$ of this emulsion were transferred into different test tubes containing $0.35 \mathrm{ml}$ of test samples. BHT was used for comparative purposes. The tubes were placed, at $50^{\circ} \mathrm{C}$, in a water bath. Absorbance of all the samples at 490 $\mathrm{nm}$ were taken at zero time $(\mathrm{t}=0)$, the measurement of the absorbance was continued, until the colour of the $\beta$-carotene disappeared in the control reaction $(\mathrm{t}=180 \mathrm{~min})$, at $15 \mathrm{~min}$ intervals. A mixture prepared as above, without $\beta$-carotene, served as blank. All determinations were performed in triplicate. The antioxidant activity (AA) of the extracts was evaluated in terms of bleaching of the $\beta$-carotene using the following formula:

$$
\left.\mathrm{AA}=\% \text { inhibition }=100\left[1-(\mathrm{A} 0-\mathrm{At}) / \mathrm{A}^{\circ} 0-\mathrm{A}^{\circ} \mathrm{t}\right)\right]
$$

Where $\mathrm{A} 0$ and $\mathrm{A}^{\circ} 0$ were the absorbance values measured at zero time of the incubation for test sample and control, respectively. At and $\mathrm{A}^{\circ} \mathrm{t}$ were the absorbances measured in the test sample and control, respectively, after incubation for $180 \mathrm{~min}$ [23].

\section{Reducing power}

The ferric-reducing power (FRAP) of the extracts and reference compound was tested using the assay of Oyaizu [24]. Ethanol extracts $(1 \mathrm{ml})$ as well as ascorbic acid as reference (all at concentration 500 $\mu \mathrm{g} / \mathrm{mL}$ ) for comparative purposes was mixed with $2.50 \mathrm{ml}$ of a 0.2 $\mathrm{M}$ sodium phosphate buffer $(\mathrm{pH}=6.6)$ and $2.50 \mathrm{ml}$ of $1 \%$ potassium ferricyanide $\left(\mathrm{K}_{3} \mathrm{Fe}(\mathrm{CN})_{6}\right)$, and incubated in a water bath at $50^{\circ} \mathrm{C}$ for $20 \mathrm{~min}$. Then, $2.50 \mathrm{ml}$ of $10 \%$ trichloroacetic acid were added to the mixture that was centrifuged at $3000 \mathrm{rpm}$ for $10 \mathrm{~min}$. The supernatant $(2.50 \mathrm{ml})$ was then mixed with $2.50 \mathrm{ml}$ distilled water and $0.50 \mathrm{ml}$ of $0.1 \%$ ferric chloride solution. The intensity of the blue-green colour was measured at $700 \mathrm{~nm}$. The increase in the absorbance of the reaction indicated the increase in reducing power of the extracts [24].

\section{Statistical analysis}

All tests were carried out in triplicate and the results were presented as the mean \pm standard deviation. Analysis of variance (ANOVA) was carried out using Origin 6.1. Differences at ${ }^{*} \mathrm{P}<0.05$ and ${ }^{* *} \mathrm{P}<0.01$ were considered statistically significant. Pearson's correlation $\left(\mathrm{R}^{2}\right)$ was carried out to study the relationships between different analytical parameter.

\section{Results and Discussion}

The evaluation of yields of extracts reveals the following order : chetoui $>$ Gerboua $>$ Lucques $>$ Meski $>$ Sevillane $>$ Limouni $>$ Rosicola $>$ Chemlali (Table 1 ). This difference was probably related to genetic feature of each variety since its growth is in the same climatic and geographical conditions and the extraction was carried out with the same solvent. The total phenol (TP) and flavonoid (TF) content of olive leaves, obtained from different varieties were shown in Table 1. 


\begin{tabular}{|l|l|l|l|l|l|}
\hline Varieties & $\begin{array}{l}\text { Extraction } \\
\text { yields }\end{array}$ & Total phenols & \multicolumn{3}{l|}{ Total flavonoïdes } \\
\hline & & Our study & $\begin{array}{l}\text { Previous } \\
\text { studies }\end{array}$ & Our study & $\begin{array}{l}\text { Previous } \\
\text { studies }\end{array}$ \\
\hline Gerboua & $40.00^{\mathrm{a}}$ & $142.21 \pm 3.53^{\mathrm{a}}$ & & $125.64 \pm 3.36^{\mathrm{a}}$ & \\
\hline Limouni & $33.66^{\mathrm{a}, \mathrm{e}, \mathrm{f}}$ & $144.19 \pm 10.27^{\mathrm{b}}$ & & $120.88 \pm 0.78^{\mathrm{b}, \mathrm{c}, \mathrm{d}, \mathrm{e}, \mathrm{f}}$ & \\
\hline Chetoui & $46.00^{\mathrm{c}, \mathrm{d}, \mathrm{f}}$ & $102.32 \pm 1.18^{\mathrm{a}, \mathrm{b}}$ & $24.36[28]$ & $94.03 \pm 4.19^{\mathrm{a}, \mathrm{c}, \mathrm{d}, \mathrm{f}}$ & $15.83[28]$ \\
\hline Chemlali & $28.33^{\mathrm{a}, \mathrm{b}}$ & $99.71 \pm 11.45$ & & $82.74 \pm 10.73^{\mathrm{a}, \mathrm{b}}$ & \\
\hline Sevillane & 35.00 & $73.05 \pm 15.52^{\mathrm{a}}$ & & $56.75 \pm 6.72^{\mathrm{a}, \mathrm{b}}$ & \\
\hline Lucques & $39.00^{\mathrm{b}, \mathrm{c}, \mathrm{e}}$ & $106.80 \pm 9.24^{\mathrm{a}, \mathrm{b}}$ & & $97.74 \pm 12.67^{\mathrm{a}, \mathrm{c}, \mathrm{d}, \mathrm{e}}$ & \\
\hline Rosicola & $33.00^{\mathrm{a}}$ & $91.90 \pm 11.04^{\mathrm{a}}$ & & $76.01 \pm 8.72^{\mathrm{a}, \mathrm{c}}$ & \\
\hline Meski & $36.33^{\mathrm{a}, \mathrm{b}, \mathrm{c}, \mathrm{d}}$ & $110.03 \pm 20.04$ & & $91.32 \pm 1.13^{\mathrm{a}, \mathrm{c}, \mathrm{d}}$ & \\
\hline $\begin{array}{l}\text { Olea } \\
\text { europea }\end{array}$ & & & $144[25]$ & & $1.47[25]$ \\
\hline & & & $40.27[26]$ & & $16.78[26]$ \\
\hline & & & $1.60[27]$ & & \\
\hline
\end{tabular}

Results are expressed \pm SD of the three replicates

For each variety, values in the same column bearing different letters are significantly different $(a, b, c, d, e$ and $f)$ at $p<0.05$ and $p<0.01$

Table 1: Yield of extraction (\%), total phenols (mgGAE/g ) and tota flavonoïdes $(\mathrm{mgCE} / \mathrm{g}))$ in olive leaves extracts.

The means of TP in olive leaves extracts in terms of mg GAE/g of dry material ranged from $73.05 \pm 15.52$ to $144.19 \pm 10.27(\mathrm{p}<0.05)$. The highest amount was observed in the order Limouni $>$ Gerboua $>$ Meski $>$ Chetoui compared to Sevillane content which had the lowest amount. Our study showed a high level of TP compared to other investigations reported by Skerget et al., Makris et al., Hayes et al., and Abaza et al. (Table 1). Moreover, Mylonaki et al. found the maximum theoretical yield of total polyphenol content to be $2.50 \pm 0.76$ using optimal recovery techniques of polyphenol from olive while our results were higher in spite of the use of a classic technique of extraction [25-29]. Our data revealed a difference in TP content between most varieties such as Lucques variety with $106.80 \pm 9.24$ and Limouni variety with $144.19 \pm 10.27(\mathrm{p}<0.01)$. Tunisian varieties contained relatively higher levels of total phenolics than the Spanish and Italian varieties. This was probably due to the natural climatic conditions of Tunisian varieties.

The TF content was also expressed as $\mathrm{mg} \mathrm{CE} / \mathrm{g}$ of dry material and ranged from $56.57 \pm 6.0$ to $125.64 \pm 3.36(\mathrm{p}<0.05)$. Varieties of Gerboua exhibited an important amount of TF followed by Limouni and Lucques. Sevillane still had the lowest level of TF compared to the other varieties, whereas it was superior to those reported in previous studies $[25,26,28]$ (Table 1). Drying method could influence the amount of obtained polyphenol. Another previous study showed that microwave drying avoided ester hydrolysis of saponins, which occurred with airdrying [30]. The drying technique using microwave energy was based on the direct effect of microwaves on molecules by ionic conduction and dipole rotation which took place simultaneously [31]. Moreover, the variation found in the phenolic and flavonoid content of the olive leaves extract reported by different studies could be due to the different methods applied for extraction (extraction technique, solvent nature and time of extraction) and also the influence of the sample origin.

Chromatographic profiles of the different cultivars studied showed no difference in qualitative composition (Figure 1). Oleuropein was the major compound of the leaf extract. The identification of oleuropein was based on the comparison of the chromatographic retention time, UV absorbance spectra comparison with the authentic standard and confirmed by results of studies carried out by Savournin et al. and Lee-Huang Zhang et al. using the same HPLC conditions [21,32]. The obtained analytical data concerning oleuroprein contents in Olea eurpaea leaves were shown in Table 2. A high amount of oleuropein was obtained using aqueous ethanol $(70 \%, v / v)$ as an extraction solvent $[17,33]$. In fact, we have chosen ethanol as a more preferable solvent because of its nontoxic effect, environmentally safe role and inexpensive feature. Besides, the study of Altiok et al. showed that water had an important role in extraction processes by increasing the diffusion of extractable polyphenol through the plant tissues [33]. In our study, Oleuropein content reached $57.24 \mathrm{mg} / \mathrm{g}$ of dry weight and was far in excess in comparison with the other phenolics. These data confirm how olive leaves are a source of oleuropein [5,34].

The isocratic HPLC method described in our study allowed a rapid separation and an identification of the major compounds of olive tree leaves. In fact, the analysis by HPLC using solvent gradient gave a no stable line base and no good separation of peaks. Indeed, the isocratic method could be used for the routine analysis of leaves extracts and industrial products $[21,32]$. The peak areas from a high-performance liquid chromatography analysis of biophenols extracted from olive leave, especially oleuropein, can been used as chemotaxonomic markers to construct chemometric models in order to discriminate and classify the varieties of Olea europea olive trees growth in same geographical zone. In our investigation, Oleuropein was present in high amount in extracts from different varieties. This chemical study showed intrinsic variations among sampled cultivars though they were collected from several varieties exposed to the same environmental (geographical, geological, and climate) and cultural (pruning, watering, and harvesting) conditions. Therefore, it could lead to characterization of varieties and evaluation of their homogeneity [34,35].

In order to evaluate the in vitro anti-oxidant activities of olive leaves extract, the DPPH radical scavenging activity of the leaf extracts were measured and compared to that of BHT $\left(\mathrm{IC}_{50}=17.02 \mu \mathrm{g} / \mathrm{ml}\right)$ (Table 3). The olive leaves extracts were able to scavenge the free radical. They exhibited antioxidant potential comparable to BHT. In fact, many varieties displayed a higher activity than $\mathrm{BHT}$ as Chemlali $\left(\mathrm{IC}_{50}=7.90 \mu \mathrm{g} / \mathrm{ml}\right)$, Rosicola $\left(\mathrm{IC}_{50}=10.88 \mu \mathrm{g} / \mathrm{ml}\right)$, Limouni $\left(\mathrm{IC}_{50}=12.25\right.$ $\mu \mathrm{g} / \mathrm{ml})$, Chetoui $\left(\mathrm{IC}_{50}=15.09 \mu \mathrm{g} / \mathrm{ml}\right)$, Meski d'Italie $\left(\mathrm{IC}_{50}=15.24 \mu \mathrm{g} / \mathrm{ml}\right.$ ) and Lucques $\left(\mathrm{IC}_{50}=16.10 \mu \mathrm{g} / \mathrm{ml}\right)$. The strong antioxidant activity of olive leaves could be attributed to their high total polyphenolic content. In fact, it was reported that polyphénols were one of the most effective antioxidative constituents in the plant [36]. Furthermore, a positive correlation between phenolic composition and antioxidant activity was proved [5,37]. Moreover, antioxidant activities could be attributed to

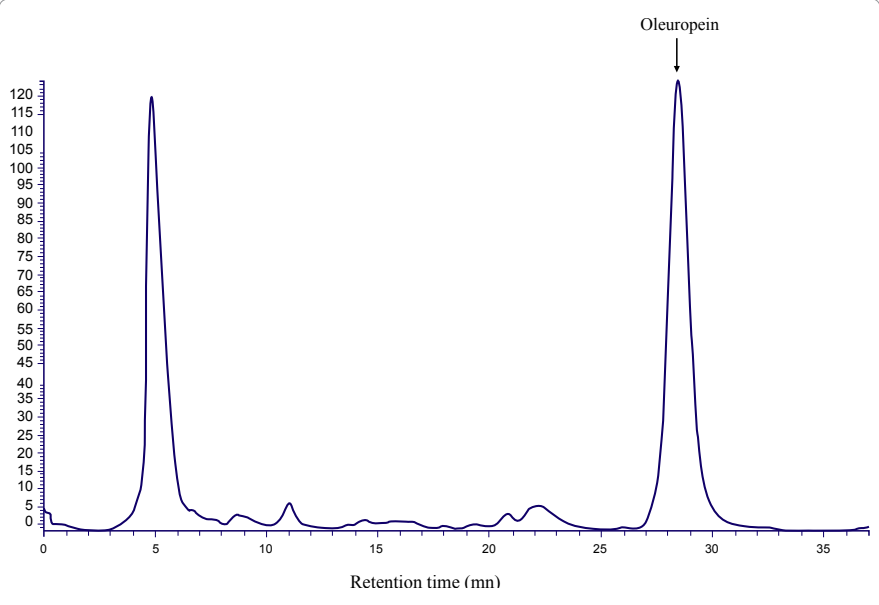

Peak before 6 min corresponded to the solvent front

Figure 1: HPLC chromatogram of Limouni olive leaf extract (Tunisian). 
the higher oleuropein amount in olive leaves from different varieties. We did not observe a correlation between oleuropein content and anti-radical activity, though high oleuropein content corresponded to high anti-radical activity for some varieties. We observed a negative correlation between $\mathrm{IC}_{50}$ values and oleuropein content only for four varieties; Gerboua, Lucques, Meski and Chetoui $\left(\mathrm{R}^{2}=-0.94\right)$. The good anti-radical activity of oleuropein could be due to the presence of the hydroxyl groups in its chemical structure (Figure 2). According to these results, the olive leaves extracts could prevent oxidative damage in system as a biological result of its ability to scavenge oxygen species such as hydroxyl radicals [27].

Beta-carotene bleaching was measured by the decrease in the initial absorbance at $490 \mathrm{~nm}$ and was slowed down in the presence of the extract. According to the results shown in figure 3, we found that Chemlali and Chetoui varieties had the higher inhibition percentage of beta-carotene. Its profiles showed 70\% inhibition during $100 \mathrm{~min}$, which were as strong as the synthetic BHT. However, Lucques, Meski, Sevillane, Gerboua and Limouni varieties showed the same activities and were less effective in minimizing the oxidation of lipids. Rosicola varieties had the lowest activity.

The $\mathrm{Fe}^{3+}-\mathrm{Fe}^{2+}$ transformation in the presence of sample extract obtained from different varieties $(0.5 \mathrm{mg} / \mathrm{ml})$ was investigated to measure the reducing power of each extract. As shown in Table 3, the olive leaves extracts of different varieties demonstrated powerful $\mathrm{Fe}^{3+}$ reducing ability with statistically differences. The higher reduced power was observed in olive leaves extract of Chemlali variety followed by Gerboua and Sevillane. The results demonstrate that olive leaves extract from different varieties had marked ferric ions $\left(\mathrm{Fe}^{3+}\right)$ reducing ability and electron donor properties for neutralizing free radicals by forming stable products. However, this reducing power was lower than the standard antioxidant used. The reducing power reflects the

\begin{tabular}{|l|l|}
\hline & Oleuropein $(\mathrm{mg} / \mathrm{g}$ of dry leaves) \\
\hline Gerboua & $45.021 .59^{\mathrm{a}}$ \\
\hline Limouni & $52.205 .60^{\mathrm{a}, \mathrm{b}, \mathrm{c}, \mathrm{d}, \mathrm{e}, \mathrm{f}}$ \\
\hline Che'toui & $57.24 \pm 2.05^{\mathrm{a}, \mathrm{b}, \mathrm{c}, \mathrm{d}, \mathrm{e}, \mathrm{f}}$ \\
\hline Chemlali & $47.421 .41^{\mathrm{b}}$ \\
\hline Sevillane & $30.762 .64^{\mathrm{a}, \mathrm{b}, \mathrm{c}, \mathrm{e}}$ \\
\hline Lucques & $52.121 .96^{\mathrm{a}, \mathrm{b}, \mathrm{c}, \mathrm{d}}$ \\
\hline Rosicola & $48.481 .10^{\mathrm{a}, \mathrm{c}, \mathrm{e}}$ \\
\hline Meski d'Italie & $52.631 .95^{\mathrm{a}, \mathrm{b}, \mathrm{d}}$ \\
\hline
\end{tabular}

Results are expressed \pm SD of three replicates

For each variety, values in the same column bearing diiffrents letters

(a, b, c, d, e, and f) are significantly different at $p<0.05$ and $p<0.01$

Table 2: Contents (as $\mathrm{mg} / \mathrm{g}$ dry weight) of oleuropein in different olive leaves varieties determined by HPLC.

\begin{tabular}{|c|c|c|}
\hline & IC50 $(\mathrm{ug} / \mathrm{ml})$ & FRAP (absorbance at 700 \\
\hline Gerboua & $18.64 \pm 7.43$ & $0.83 \pm 0.04$ \\
\hline Limouni & $12.25 \pm 0.47$ & $0.68 \pm 0.01$ \\
\hline Che'toui & $15.09 \pm 1.76$ & $0.66 \pm 0.09$ \\
\hline Chemlali & $7.90 \pm 0.56$ & $0.84 \pm 0.03$ \\
\hline Sevillane & $17.02 \pm 1.54$ & $0.75 \pm 0.07$ \\
\hline Lucques & $16.10 \pm 0.06$ & $0.67 \pm 0.02$ \\
\hline Rosicola & $10.88 \pm 1.78$ & $0.54 \pm 0.00$ \\
\hline Meski d'Italie & $15.24 \pm 0.20$ & $0.56 \pm 0.03$ \\
\hline Ascorbic acid & $\mathrm{n} . \mathrm{d}$ & $2.10 \pm 0.11$ \\
\hline BHT & $17.02 \pm 3.55$ & n.d \\
\hline
\end{tabular}

Means $\pm \operatorname{SD}(n=3)$

n.d: not determined

Table 3: Antiradical activity and reducing ability of each olive leaves variety.

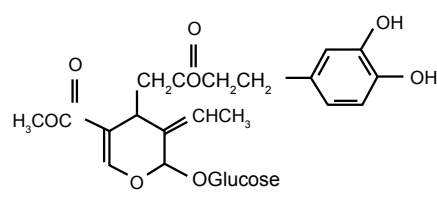

Figure 2: Chemical structure of oleuropein [38].

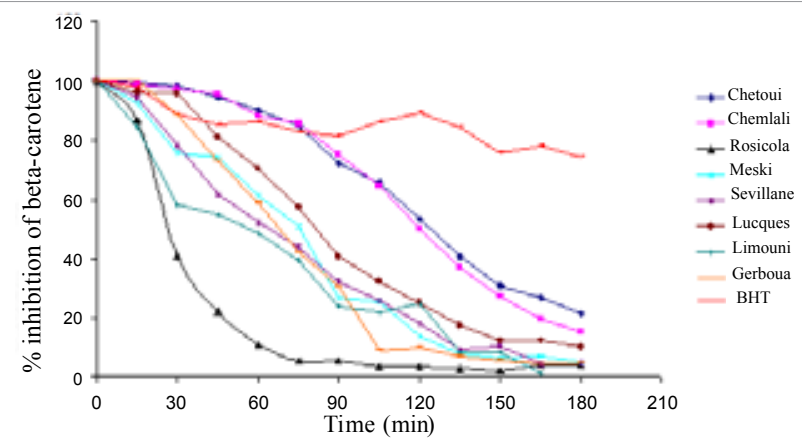

Figure 3: The antioxidant activities of olive leaves extracts of different varieties as determined by the beta-carotene bleaching test.

electron donating capacity of bioactive compound and was associated with antioxidant activity. The reducing capacity of compound might be served as an indicator of its potential antioxidant activity [38].

\section{Conclusion}

There are a wide number of systems available in order to evaluate the antioxidant properties of the extracts. The results of a single method can give only a reductive idea about the antioxidant activity of the plant. For that reason, in our study, we combined different techniques with the aim of giving a global idea about properties for each cultivar. Each olive variety had its own feature, however we could confirm that olive tree was a wide source of polyphenols, especially a source of oleuropein and it possesses a good antioxidant activity and strong reduced power. These results could be due to the solvent nature used for extraction. In fact, aqueous ethanol $(70 \%, \mathrm{v} / \mathrm{v})$ was the best solvent of extraction since it has exhibited a good antioxidant activity. Also, it yielded a high polyphenol and oleuropein content. It is important to reveal that the antioxidant assays carried out in this research are strictly based on chemical reaction in vitro and do not necessarily correlate with their activity in biological system. However, they can be useful indicators on the potency of some compounds in order to valorize plant species and use them in biological models.

\section{References}

1. Trush M, Egner P, Kensler W (1994) Myeloperoxidse as a biomarker of skin irritation and inflammation. Food Chem Toxicol 32: 143-147.

2. Jung $\mathrm{CH}$, Seog HM, Choi IW, Choi HD, Cho HY (2005) Effects of wild ginseng (Panax ginseng C.A. Meyer) leaves on lipid peroxidation levels and antioxidant enzyme activities in streptozotocin diabetic rats. J Ethnopharmacol 98: 245250.

3. Hadjaz F, Besret S, Martin-Nizard F, Yous S, Dilly S, et al. (2011) Antioxydant activity of $\beta$-carboline derivatives in the LDL oxidation model. Eur J Med Chem 46: $2575-2585$.

4. Jayalakshmi CP, Sharma JD (1986) Effect of Butylated Hydroxyanisole (BHA) and Butylated Hydroxytoluene (BHT) on Rat Erythrocytes. Environ Res 41: 235-238.

5. Bouaziz M, Fki I, Jemai H, Ayadi M, Sayadi S (2008) Effect of storage on refined and husk olive oils composition: Stabilization by addition of natural antioxidants from Chemlali olive leaves. Food Chem 108: 253-262. 
Citation: Salah MB, Abdelmelek H, Abderraba M (2012) Study of Phenolic Composition and Biological Activities Assessment of Olive Leaves from different Varieties Grown in Tunisia. Med chem 2: 107-111. doi:10.4172/2161-0444.1000124

6. Gardner PT, White TAC, McPhail DB, Duthie GG (2000) The relative contributions of vitamin $\mathrm{C}$, carotenoids and phenolics to the antioxidant potential of fruit juices. Food Chem 68: 471-474.

7. Tabera J, Guinda A, Ruiz-Rodriguez A, Senorans FJ, Ibanez E, et al. (2004) Countercurrent Supercritical Fluid Extraction and Fractionation of High-AddedValue Compounds from a Hexane Extract of olive Leaves. J Agric Food Chem 52: 4774-4779

8. Briante R, Patumi M, Terenziani S, Bismuto E, Febbraio F, et al. (2002) Olea europaea L. leaf extract and derivatives:antioxidant properties. J Agric Food Chem 50: 4934-4940.

9. Le Tutour B, Guedon D (1992) Antioxidative activities of Olea Europea leaves and related phenolic compounds. Phytochemistry 31: 1173-1178.

10. Sudjana AN, D'Orazio C, Ryan V, Rasool N, Ng J, et al. (2009) Antimicrobia activity of commercial Olea europaea (olive) leaf extract. Int J Antimicrob Agents 33: 461-463.

11. Esmaeili-Mahani S, Rezaeezadeh-Roukerd M, Esmaeilpour K, Abbasnejad M, Rasoulian B, et al. (2010) Olive (Olea europaea L.) leaf extract elicits antinociceptive activity, potentiates morphine analgesia and suppresses morphine hyperalgesia in rats. J Ethnopharmacol 132: 200-205.

12. Micol V, Caturla N, Pérez-Fons L, Mas V, Pérez L, et al. (2005) The olive leaf extract exhibits antiviral activity against viral haemorrhagic septicaemia rhabdovirus (VHSV). Antiviral Res 66:129-136.

13. Caturla N, Pérez-Fons L, Estepa A, Micol V (2005) Differential effects of oleuropein, a biophenol from Olea europaea, on anionic and zwiterionic phospholipid model membranes. Chem Phys Lipids 137: 2-17.

14. Somova L, Shode F, Ramnanan P, Nadar A (2003) Antihypertensive, antiatherosclerotic and antioxidant activity of triterpenoids isolated from Olea europaea, subspecies africana leaves. J Ethnopharmacol 84: 299-305.

15. Hayes JE, Stepanyan V, Allen P, O'Grady MN, O'Brien NM, et al. (2009) The effect of lutein, sesamol, ellagic acid and olive leaf extract on lipid oxidation and oxymyoglobin oxidation in bovine and porcine muscle model systems. Meat Sci 83: 201-208.

16. Singh I, Mok M, Christensen AM, Turner AH, Hawleyl JA (2008) The effects of polyphenols in olive leaves on platelet function. Nutr Metab Cardiovasc Dis 18: $127-132$.

17. Abaza L, Talorete TP, Yamada P, Kurita Y, Zarrouk M, et al. (2007) Induction of Growth Inhibition and Differentiation of Human Leukemia HL-60 Cells by Tunisian Gerboui Olive Leaf Extract. Biosci Biotechnol Biochem 71: 1306-1312.

18. Singelton VL, Orthofer R, Lamuela-Raventos RM (1999) Analysis of tota phenols and other oxidation substrates and antioxidants by means of FolinCiocalteu reagent. Methods Enzymol 299: 152-178.

19. Spencer J (2008) Flavonoids: Modulators of brain function. Br J Nutr 99: 60-77

20. Dewanto V, Wu X, Adom KK, Liu RH (2002) Thermal processing enhances the nutritional value of tomatoes by increasing total antioxidant activity. J Agric Food Chem 50: 3010-3014

21. Savournin C, Baghdikian B, Elias R, Dargouth-Kesraoui F, Boukef K, et al (2001) Rapid High-Performance Liquid Chromatography Analysis for the Quantitative Determination of Oleuropein in Olea europaea Leaves. J Agric Food Chem 49: 618-621.

22. Hanato T, Kagawa H, Yasuhara T, Okuda T (1988) Two new flavonoids and other constituents in licorice root: their relative astringency and radical scavenging effects. Chem Pharm Bull 36: 2090-2097.

23. Pratt D (1980) Natural antioxidants of soybean and other oil-seeds.In M. G. Simic \& M. Karel (Eds.) Autoxidation in food and biological systems 283-292. New York: Plenum Press.

24. Oyaizu M (1986) Studies on products of browning reaction: Antioxidative activity of browning reaction products prepared from glucosamine. Jpn J Nutr. 44: 307-315.

25. Skerget M, Kotnik P, Hadolin M, Rizner Hras A, Simonic M, et al. (2005) Phenols, proanthocyanidins, flavones and flavonols in some plant materials and their antioxidant activities. Food Chemistry 89: 191-198.

26. Makris DP, Boskou G, Andrikopoulos NK (2007) Polyphenolic content and in vitro antioxidant characteristics of wine industry and other agri-food solid waste extracts. J Food Compost Anal 20: 125-132.

27. Hayes JE, Allen P, Brunton N, O'Grady MN, Kerry JP (2011) Phenolic composition and in vitro antioxidant capacity of four commercial phytochemical products: Olive leaf extract (Olea europaea L.), lutein, sesamol and ellagic acid. Food Chemistry 126: 948-955.

28. Abaza L, Ben Youssef N, Manai H, Mahjoub Haddada F, Methenni K, et al (2011) Chétoui olive leaf extracts: influence of the solvent type on phenolics and antioxidant activities. Grasas y Aceites 62: 96-104.

29. Mylonaki S, Kiassos E, Makris D, Kefalas P (2008) Optimisation of the extraction of olive (Olea europaea) leaf phenolics using water/ethanol-based solvent systems and response surface methodology. Anal Bioanal Chem 392 977-985.

30. Elias R, Diaz Lanza A, Vidal-Ollivier E, Maillard C, Crespin F, et al. (1991) Influence du procédé de séchage et du degré alcoolique sur l'extraction de l'hédérasaponine $C$ et de l'hédérine a' partir des feuilles de Hedera helix $L$. J Pharm Belg 46: 177-181.

31. Eskilsson CS, Björklund E (2000) Analytical-scale microwave-assisted extraction. J Chromatogr A 902: 227-250.

32. Lee-Huang S, Zhang L, Lin Huang PL, Chang YT, Huang PL (2003) Anti-HIV activity of olive leaf extract (OLE) and modulation of host cell gene expression by HIV-1infection and OLE treatment. Biochem Biophys Res Commun 307: 1029-1037.

33. Altıok E, Bayçın D, Bayraktar O, Ulku S (2008) Isolation of polyphenols from the extracts of olive leaves (Olea europaea L.) by adsorption on silk fibroin Separation and Purification Technology 62: 342-348.

34. Japón-Luján R, Luque de Castro MD (2008) Liquid-Liquid Extraction for the Enrichment of Edible Oils with Phenols from Olive Leaf Extracts. J Agric Food Chem 56: 2505-2511.

35. Ranalli A, Contento S, Lucera L, Di Febo M, Marchegiani D, et al. (2006) Factors affecting the contents of iridoid oleuropein in olive leaves (Olea europaea $L$ ). J Agric Food Chem 54:434-440.

36. Velioglu YS, Mazza G, Gao L, Oomah BD (1998) Antioxidant activity and tota polyphenolics in selected fruits, vegetables, and grain products. J Agric Food Chem 46: 4113-4117.

37. Arnous A, Makris DP, Kefalas P (2002) Correlation of Pigment and Flavano Content with Antioxidant Properties in Selected Aged Regional Wines from Greece. J Food Compost Anal 15: 655-665.

38. Benavente-Garcia O, Castillo J, Lorente J, Ortuño A, Del Rio JA (2000) Antioxidant activity of phenolics extracted from Olea europaea L. leaves. Food Chem 68: 457-462 